\title{
TAMARIX APHYLLA: A NEWLY INVASIVE TREE IN SOUTHERN NEVADA
}

\author{
Lawrence R. Walker ${ }^{1}$, Pamela L. Barnes ${ }^{1}$, and Elizabeth A. Powell ${ }^{1}$
}

\begin{abstract}
AвstRact.-In the southwestern United States, the nonnative athel pine (Tamarix aphylla) was presumed to be sterile and therefore not as likely to spread as its widely distributed, nonnative congener, T. ramosissima. However, at Lake Mead National Recreation Area (LMNRA) in southern Nevada, populations of T. aphylla have recently spread beyond their limited pre-1990 distribution and now form extensive monospecific stands. Over a 3-year period, we quantified seed production and germination from $60 \mathrm{~T}$. aphylla trees at LMNRA. The annual mean seed production period was 50.6 days, and the mean potential germination (under laboratory conditions) was $22 \%$, indicating that T. aphylla trees at LMNRA are capable of sexual reproduction in southern Nevada. No seeds germinated in field experiments, apparently because of high soil salt levels. However, seedling regeneration is becoming increasingly common at LMNRA. Tamarix aphylla trees occupied a distinct zone along the shoreline of Lake Mead, above T. ramosissima in elevation and below native Larrea tridentata communities, suggesting either competitive exclusion or differential resource utilization. The $T$. aphylla zone tended to have the highest mean values for total vegetation cover, leaf litter depth, soil salinity, soil moisture, $\mathrm{pH}$, total Kjeldahl nitrogen, and soil organic matter. The capacity for sexual reproduction of this alien plant, combined with a suite of characteristics shared with the invasive T. ramosissima (e.g., drought tolerance and copious saline leaf litter), makes T. aphylla a potentially invasive species along the shores of LMNRA and other mesic areas in the desert Southwest.
\end{abstract}

Key words: Tamarix aphylla, Tamarix ramosissima, invasions, drawdown zone, saltcedar, athel pine, Nevada, reservoir, riparian ecology, Lake Mead.

Floodplains provide corridors for plant invasions (Williams and Wiser 2004), particularly in arid ecosystems where access to water is limited (Brokaw 1998). Extreme fluctuations of water levels around artificial impoundments (Dynesius and Nilsson 1994, Tallent-Halsell and Walker 2002) provide opportunities that favor the invasion of woody plants with deep roots. The shoreline of Lake Mead in the Mojave Desert in southern Nevada, like many impoundments, fluctuates periodically depending on patterns of water removal for irrigation in southern California and rainfall-in this case from the headwaters of the Colorado River. These fluctuations create a drawdown zone that is increasingly dominated by nonnative plants that are capable of surviving periodic inundation and rapidly recolonizing newly exposed banks. Two woody invaders of this drawdown zone are Tamarix ramosissima Ledeb. (from central Asia) and T. aphylla (L.) Karst. (from North Africa and the Middle East). Tamarix ramosissima is an invasive shrub that dominates many watercourses throughout the desert Southwest and alters flooding and erosion patterns, fire frequency, ground water levels, and soil chem- istry (Busch and Smith 1995, Walker and Smith 1997, Di Tomaso 1998). High water use by $T$. ramosissima leads to lowered water tables (Waisel 1960b, Sala et al. 1996) and competition with native species (Cleverly et al. 1997, Sher et al. 2002, Sher and Marshall 2003). However, very little is known about the ability of $T$. aphylla to invade watercourses or effect ecosystem change.

Tamarix aphylla is larger (up to $10 \mathrm{~m}$ tall) than its congener and shares many physiological characteristics such as extreme drought tolerance, rapid growth, and copious saline leaf litter. It grows on sandy soils along riverbanks in its native habitat (Baum 1967, Baum 1978, Abd El-Ghani 2000). Vegetative reproduction from stem (not root) sprouting is common (Lyon 1924), but sexual reproduction is rare (Baum 1967) and seed viability is low (Waisal 1960a). However, sexual reproduction does occur in well-watered areas such as around greenhouses (Danin 1981). The presence of extensive stands of $T$. aphylla reflects flood events (Danin 1999) and high water marks around lake beds (Goldsmith and Smart 1982).

${ }^{1}$ Department of Biological Sciences, University of Nevada, Las Vegas, Box 454004, 4505 Maryland Parkway, Las Vegas, NV 89154-4004. 
Tamarix aphylla was introduced in the southwestern deserts of the USA in 1911 (Baum 1967), where it has been considered a benign, sterile shade tree that survives arid conditions but rarely spreads (Hoddenbach 1989, Neill 1989, Meyers-Rice 1997; W. Neill, personal communication, 1999). However, following its introduction into Australia in 1930 (Fuller 1998), T. aphylla invaded several riparian systems, most notably the Finke River following a 1974 flood (Griffin et al. 1989), resulting in its listing as a weed of national significance (Thorp and Lynch 2000). Tamarix aphylla is now also considered a weed in Hawaii (Cronk and Fuller 1995), where it was introduced as an ornamental shade tree (Lyon 1924).

Tamarix aphylla was planted at the Lake Mead National Recreation Area (LMNRA) during the 1950s as part of a program to enhance visitor use of the newly created park by providing shade, windbreaks, and a drought-tolerant ornamental. There has been no apparent concern about the tree spreading in the LMNRA despite efforts to eradicate $T$. ramosissima from shorelines and springs during the last 15 years. Aerial photographs from 1982 show only 4 large trees at Boulder Beach (Study Site 1) where there are now $>5000 \mathrm{~T}$. aphylla individuals, implying that rapid population growth has occurred in the last 20 years. In 1999 we recognized that $T$. aphylla trees were indeed spreading at Boulder Beach and elsewhere around Lake Mead. A survey in 2002 documented ca. 11,000 individuals along the shoreline of Lake Mead in the LMNRA (Powell unpublished data). In addition, we inadvertently found potential T. ramosissima-T. aphylla hybrids at LMNRA during this study (Barnes 2003), suggesting continuing changes in the dynamics of Tamarix. This paper addresses several questions designed to understand the invasive potential of T. aphylla: (1) Do T. aphylla trees produce seeds at LMNRA, and, if so, are those seeds capable of germinating? (2) What is the timing and duration of seed production and other phenological stages of T. aphylla populations at LMNRA? (3) Do inundation, drought, soil salinity, or leaf litter affect $T$. aphylla germination? (4) Is the distribution of T. aphylla linked to soil composition or distance from the lakeshore? (5) Is there a pattern of spatial correlation between T. aphylla and $T$. ramosissima or an age gradient within $T$.

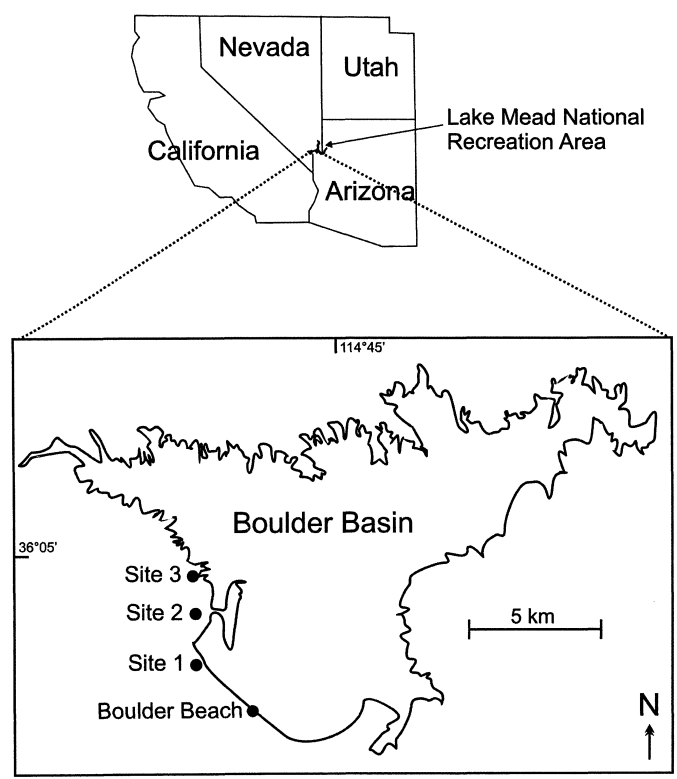

Fig. 1. Location of the 3 study sites on the western edge of the Lake Mead National Recreation Area.

aphylla stands? And (6) do apparent T. ramosissima-T. aphylla hybrids also produce seeds?

\section{Methods \\ Study Area}

This study was located in the LMNRA in Nevada, along the western shore of Boulder Basin (Fig. 1). Lake Mead is the reservoir created by Hoover Dam on the lower Colorado River. Located within the Mojave Desert, the study area has mean summer high temperatures $>37^{\circ} \mathrm{C}$ and a mean yearly precipitation of $<130 \mathrm{~mm}$. The study (from June 2000 to December 2002) took place at 3 study sites within a $5-\mathrm{km}$ stretch of shoreline. Tamarix aphylla stands extended 250, 500, and $300 \mathrm{~m}$ along the shoreline at Site 1 (Boulder Beach), Site 2 (Tour Boat), and Site 3 (Saddle Cove), respectively. Vegetation was similar at each site starting with a mudflat filled with snags and seedlings of $T$. ramosissima along the shoreline, then a zone of larger $T$. ramosissima, a zone of overlap between $T$. ramosissima and $T$. aphylla, a T. aphylla zone, and, most distant from the shoreline, desert shrubs dominated by Larrea tridentata (Sessé \& Moc. ex DC.) Coville. At each site, a 75-m-long baseline was placed parallel to the shoreline at water level 
at a random location within the T. aphylla stand. Within each 15-m section of baseline, a random starting point was selected for a transect perpendicular to the shoreline and baseline. Each of the 15 transects was, in turn, divided into segments $15 \mathrm{~m}$ long $(n=13-17$ segments, depending on the width of the $T$. aphylla stand). Each transect ended $30 \mathrm{~m}$ into the Larrea zone. Within each segment, one 6 $\times 6$-m plot, used for soil and vegetation measurements, was placed randomly on the south side of the transect but at least $1 \mathrm{~m}$ from any adjacent plots (see below; $n=214$ plots). Elevations of each plot were determined with a global positioning system.

\section{Phenology and Seed Germination}

From 2000 to 2002, we monitored the reproductive phenology of 20 randomly chosen T. aphylla trees $(>1 \mathrm{~m}$ tall) in each of the 3 sites. Every 2 weeks we noted the presence or absence of flower buds, flowers, fruits, and seeds on each tree. Phenological stages overlapped considerably within trees and thus were not exclusive. When present, seeds from 3 inflorescences per tree were gathered and pooled. We then selected 25 seeds from each pooled sample and placed them (at room temperature and ambient light) in a petri dish on filter paper where they were kept moist with deionized water, providing optimal conditions for germination. Germination, defined as cotyledon emergence, was monitored at least every other day for 30 days. Germination rate was recorded as $\mathrm{GT}_{50}$, or the number of days for $50 \%$ of all germination to occur. For a single $7-\mathrm{m} T$. aphylla tree (of average height and productivity), we estimated total seed production from the number of seeds per sampled inflorescence multiplied by the number of inflorescences on that tree.

In October 2001, we conducted paired field and greenhouse germination experiments to determine if drought or surface litter inhibited germination within T. aphylla stands. In the field, every $0.5 \mathrm{~m}$ along a $30-\mathrm{m}$ transect at Site 2 , a plot $(n=60)$ was created by sinking a $6 \times$ $6 \times 4$-cm deep, bottomless plastic form $2 \mathrm{~cm}$ into the ground, leaving $2 \mathrm{~cm}$ aboveground to contain water. The soil from each hole, with surface litter removed, was replaced to its initial level, and 25 T. aphylla seeds (pooled from collections from 25 trees at Site 1) were sown therein. Ten plots were randomly assigned to each of 6 treatments: (1) leaf litter addition (from a nearby live T. aphylla, to a depth of 2 $\mathrm{cm}$, representing natural conditions) with daily watering to a depth of $2 \mathrm{~cm}$ (i.e., $75 \mathrm{~cm}^{3}$ ); (2) leaf litter addition with weekly watering to a depth of $2 \mathrm{~cm}$; (3) leaf litter addition with only an initial, saturating watering; (4-6) matching watering treatments with no leaf litter addition. To avoid potential interference, other species that germinated in the plots were removed. We also monitored potential germination of voluntary $T$. aphylla in $6 \times 6$-cm plots adjacent to each sown plot. In the greenhouse, we established an identical experiment of 6 treatments using trays of identical dimensions (but with drain holes in the intact bottom) filled with field soil. Trays were rotated daily to reduce any differential impacts of variation in the greenhouse environment. Both field and greenhouse germination were monitored for 30 days.

Seed germination was tested under both field and indoor storage conditions using pooled seeds collected in October 2001 from 45 trees at Site 1. Some seeds were immediately placed in 6 petri dishes ( 25 seeds per dish), wetted, and observed for 30 days. Other seeds were placed in mesh bags on the soil surface at Site 1 ( 25 seeds in each of 6 bags) at each of 3 new locations of similar elevation and proximity to a T. aphylla tree. Two bags from each of the laboratory and 3 field locations were collected, and the seeds were moistened and monitored for germination 1, 4, and 56 weeks following placement. All remaining seeds were stored under dry conditions at room temperature in the laboratory.

Seeds collected in November 2002 from 25 trees at Site 1 were used in soaking (March 2003) and salinity (May 2003) tests to examine tolerance to flooding and salty field conditions. For the first test, 5 subsamples of seeds were soaked in tap water for $0,1,3,5$, or 7 days. Then 25 seeds were placed on filter paper in each of 30 covered petri dishes (6 from each soaked subsample) and germination was monitored. For the second test, we created 7 salt solutions (treatments) encompassing the range of salt concentrations observed in the field $\left(0.08-3.5 \mathrm{dS} \cdot \mathrm{m}^{-1}\right): 0.05,0.27,0.66,1.29,1.85$, 2.51 , and $3.56 \mathrm{dS} \cdot \mathrm{m}^{-1}$. For each salinity treatment, filter papers in 3 covered petri dishes containing 25 seeds were watered daily and germination was monitored. Solutions were 
made with a 2:1 ratio of $\mathrm{NaCl}$ to $\mathrm{CaCl}_{2}$ to most closely resemble field conditions. Although germination potential of these stored seeds probably declined, the nonsoaked seeds and low salt levels served as adequate controls to compare treatment effects.

\section{Soils}

Soils were sampled to a depth of $10 \mathrm{~cm}$ from every $6 \times 6-\mathrm{m}$ plot at all 3 sites in July $2001(5$ samples pooled per plot). After organic debris and large rocks had been removed, the soils were passed through a $2.5-\mathrm{mm}$-mesh sieve and processed immediately. A $50 \mathrm{~g}$ soil sample was removed and allowed to air dry for later nitrogen analysis. The remaining $200 \mathrm{~g}$ of soil were weighed and dried at $105^{\circ} \mathrm{C}$ for 3-4 days and then weighed again to determine gravimetric moisture content ([wet mass - dry mass]/dry mass). We measured the $\mathrm{pH}$ (1:1 ratio of soil to water; McLean 1982) and soil salinity (electrical resistance with a conductivity bridge on extracted water-soluble salts; Rhoades 1982) of the oven-dried soils. The air-dried sample was digested in sulfuric acid with a mercuric oxide catalyst and analyzed colorimetrically for total Kjeldahl nitrogen using an automated salicylate procedure (Alpkem 1991).

\section{Vegetation}

Within each of the $6 \times 6$-m plots, total vegetation cover and cover of Tamarix ramosissima and T. aphylla were visually estimated in 5 cover classes $(0=$ none, $1=1 \%-25 \%, 2=$ $26 \%-50 \%, 3=51 \%-75 \%, 4=76 \%-100 \%$ ). The number of individuals of both Tamarix species was counted, and heights and basal diameters were recorded for each $T$. aphylla. Individual circumferences of multiple-stemmed plants were summed. We also searched each plot for T. aphylla seedlings $<50 \mathrm{~cm}$ tall. We estimated litter depth from 5 randomly chosen locations in each plot. Four vegetation zones were defined by presence of 4 dominant woody species: Zone 1, only T. ramosissima; Zone 2, T. ramosissima and T. aphylla; Zone 3, only T. aphylla; and Zone 4, only Larrea tridentata. Zone 3 was least common.

We obtained stem cross sections of 24 trees at ground level and aged each tree by counting clearly distinguishable growth rings. Each ring presumably represents 1 year's growth (Brotherson et al. 1983, 1984, Haigh 1998). The trees selected for aging were the tallest and shortest trees within a $10-\mathrm{m}$ radius of 12 different points. These points were located either $10 \mathrm{~m}$ or $30 \mathrm{~m}$ above the lowest edge of the $T$. aphylla stand on 2 transects in each of the 3 sites.

Between July 2001 and December 2001, we randomly marked 10 individuals from a group of ca. 100 plants at Site 1 that appeared to be morphologically intermediate between T. ramosissima and T. aphylla and observed their phenological patterns. Fewer hybrids were observed at Sites 2 or 3.

\section{Statistical Analyses}

We analyzed the length of each phenological stage across sites and years with a Friedman nonparametric 2-way ANOVA (Statistix 2000). The percentages of individual trees in each stage were compared with Kruskal-Wallis 1-way ANOVA, a test also used to compare the medians (treatment, percent germination) for the lab and field viability experiments. One-way ANOVA followed by a Bonferroni comparison was used to separate means (treatment, percent germination) in the soak and salinity treatments. All percentages were arcsine square root transformed prior to analysis. Rate of germination $\left(\mathrm{GT}_{50}\right)$ was represented by the number of days to $50 \%$ germination of total germinants. We used simple linear regression to compare each soil variable and vegetation cover (using midpoints from each cover class) against distance from the baseline along the lakeshore. A Kruskal-Wallis 1-way ANOVA was used to compare each soil variable among the 4 vegetation zones following a MANOVA of all soil variables and all zones. Tree age (estimated from growth rings) was analyzed with 2-way ANOVA of ring number by site and distance. The relationship between tree height and ring number was determined by linear regression. Means are reported $\pm 1 s_{\bar{x}}$, and significance was determined at $P>0.05$.

\section{Results}

\section{Phenology}

This study documents the 1st record of sexual viability of T. aphylla in the USA. Some $T$. aphylla individuals at the 3 study sites passed through all 4 phenological stages (bud, flower, fruit, seed), culminating in substantial seed production. In 2000, 2001, and 2002 there were 37,18 , and 15 individuals, respectively, 
TABLE 1. Estimated duration of phenological events based on weekly observations of 20 T. aphylla trees at each site. The number in parentheses indicates days in each phenological stage. An asterisk indicates that the earliest dates were not measured.

\begin{tabular}{|c|c|c|c|}
\hline Year & Site 1 & Site 2 & Site 3 \\
\hline \multicolumn{4}{|l|}{$\overline{\text { BUD }}$} \\
\hline 2000 & *16 Jul-15 Oct (92) & *24 Jul-8 Oct (77) & $* 16$ Jul-15 Oct (92) \\
\hline 2001 & 25 Jul-12 Nov (111) & $25 \mathrm{Jul}-23 \mathrm{Sep}(60)$ & 25 Jul-28 Oct (96) \\
\hline 2002 & *9 Sep-20 Nov (73) & *9 Sep-20 Nov (73) & *9 Sep-25 Nov (78) \\
\hline \multicolumn{4}{|l|}{ FLOWER } \\
\hline 2000 & 16 Jul-8 Oct (85) & 24 Jul-8 Oct (77) & 16 Jul-8 Oct (85) \\
\hline 2001 & 16 Aug-28 Oct (74) & 16 Aug-25 Sep (42) & 16 Aug-7 Nov (84) \\
\hline 2002 & 9 Sep-20 Nov (73) & 9 Sep-30 Nov (83) & 9 Sep-20 Nov (73) \\
\hline \multicolumn{4}{|l|}{ FRUIT } \\
\hline 2000 & 21 Aug-1 Jan (133) & 10 Sep-8 Oct (29) & 4 Sep-1 Jan (119) \\
\hline 2001 & 16 Sep-24 Dec $(100)$ & 16 Sep-23 Sep (7) & $23 \mathrm{Sep}-24$ Dec $(93)$ \\
\hline 2002 & 19 Sep-13 Nov (56) & 26 Sep-6 Nov $(42)$ & 3 Oct-6 Nov (35) \\
\hline \multicolumn{4}{|l|}{ SEED } \\
\hline 2000 & 10 Sep-1 Jan (114) & 17 Sep-15 Oct (29) & 17 Sep-1 Jan (107) \\
\hline 2001 & 30 Sep-24 Dec (86) & $23 \operatorname{Sep}(0)$ & 14 Oct-31 Dec (79) \\
\hline 2002 & 23 Oct-6 Nov (15) & 23 Oct-6 Nov (15) & 30 Oct -6 Nov $(8)$ \\
\hline
\end{tabular}

that produced seeds from a total of 60 trees. There were no significant differences in the duration of any of the phenological stages by site or year (Barnes 2003; Table 1). However, Site 2 generally had a shorter period of seed production, and fewer trees produced seeds than trees at Sites 1 and 3. The year 2000 generally had the longest reproductive season. For all sites and years mean duration was $83.6 \pm$ 5.6 days for buds, $74.2 \pm 4.3$ days for flowers, $70.6 \pm 16.0$ days for fruits, and $50.6 \pm 15.2$ days for seeds.

\section{Seed Germination}

Germination decreased over time for seeds collected from Site 1 (Fig. 2), but total germination was higher $(F=51.74, P<0.0001)$ for seeds from Site $1(31.9 \% \pm 2.3 \%)$ than from Site $2(8.65 \% \pm 3.16 \%)$, or Site $3(3.2 \% \pm 1.19 \%)$. Maximum germination for a single tree was $88 \%$, and mean overall germination rate $\left(\mathrm{GT}_{50}\right)$ was 3.4 days. We estimated that one $7-\mathrm{m} T$. aphylla could potentially produce 250,000 500,000 seeds (7500-150,000 germinable seeds) in 1 season.

In the paired greenhouse and field plots, none of the sown seeds germinated in any of the watering or litter treatments. Seeds stored in the laboratory germinated (when moistened) after 4 weeks of dry storage, but none germinated after 56 weeks of dry storage. Field storage resulted in a more rapid decline, with no germination (under moist laboratory condi- tions) after 4 weeks in the field. Soaking $T$. aphylla seeds for 7 days significantly reduced germination $(P<0.0001)$ from an initial $41.6 \%$ $\pm 6.0 \%$ to $1.4 \% \pm 0.04 \%$ (Barnes 2003). Mean germination was reduced at or above $0.27 \mathrm{dS}$. $\mathrm{m}^{-1}$ in $\mathrm{NaCl}+\mathrm{CaCl}_{2}$ salt solutions, and no germination occurred at or above $2.51 \mathrm{dS} \cdot \mathrm{m}^{-1}$ (Fig. 3).

\section{Soil and Vegetation}

Elevation $\left(r^{2}=0.0977, P<0.0001\right)$ and soil pH $\left(r^{2}=0.5588, P<0.0001\right)$ increased with distance from the baseline while all other soil variables showed a weak decline with distance (litter depth: $r^{2}=0.0702, P=0.0001$; soil salinity: $r^{2}=0.0147, P=0.0766$; soil moisture: $r^{2}=0.0461, P=0.0016$; soil nitrogen: $\left.r^{2}=0.046, P=0.0016\right)$. There were significant differences across vegetation zones when vegetation cover and soil variables were combined (Wilks' Lambda $=0.59, P<0.0001$ ). Most of these zonal differences (Table 2) were driven by total vegetation cover (that peaked in Zone 3) and $\mathrm{pH}$ (that was least in Zone 1). Litter depth, soil salinity, and soil moisture were lowest in Zone 4. Soil nitrogen did not vary significantly across the vegetation groups. Values for all soil parameters except $\mathrm{pH}$ tended to be highest in Zone 3 (T. aphylla only).

Height of T. aphylla $\left(r^{2}=0.0305, P=\right.$ $0.0036)$, but not diameter $\left(r^{2}=0.0006, P=\right.$ $0.7085)$, increased slightly with distance from 


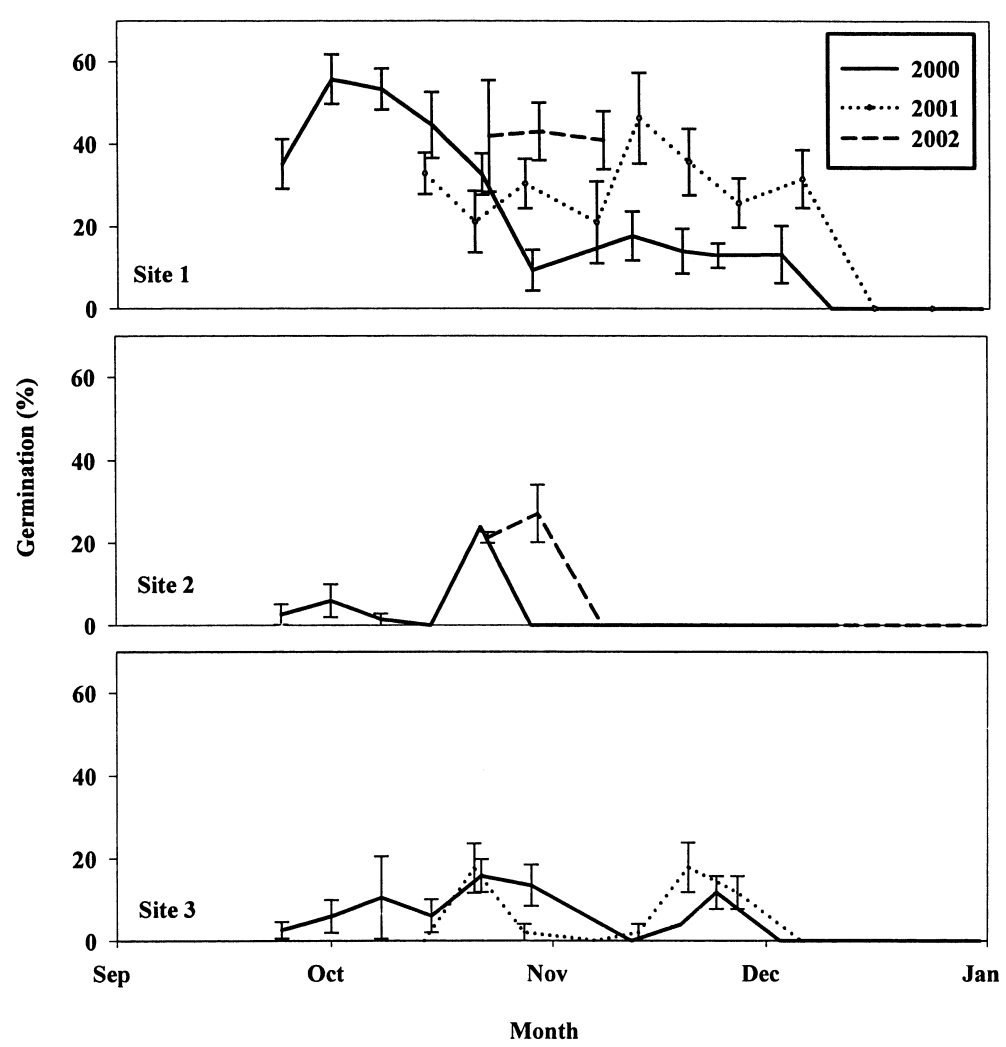

Fig. 2. Mean germination percentages $\left( \pm 1 s_{\bar{x}} ; n=20\right.$ trees per site) for Tamarix aphylla seeds by collection date.

the baseline. Mean density of T. aphylla was 0.66 trees $\cdot \mathrm{m}^{-2}\left(6600\right.$ trees $\left.\cdot \mathrm{ha}^{-1}\right)$, and density was highest $157.5 \mathrm{~m}$ from the baseline (Fig. 4A). Maximum height of T. aphylla (data not shown) had a similar pattern. Density of $T$. ramosissima peaked at $52.5 \mathrm{~m}$ from the baseline. Similarly, cover (Fig. 4B) peaked at 147.5 $\mathrm{m}$ (T. aphylla) and $67.5 \mathrm{~m}$ (T. ramosissima). No seedlings were found in the study plots but we observed numerous T. aphylla seedlings in adjacent parking lots and beach areas. The presence of taproots and lack of nearby adult trees suggest that the seedlings were not root sprouts from adult trees.

No significant interaction was found between age of $T$. aphylla and site $(P=0.6176)$ or between age and distance into the stand of trees $(P=0.9269)$; however, older trees were significantly taller $\left(r^{2}=0.676, P<0.0001\right)$. The mean age of the $T$. aphylla trees was 8.04 years. Table 3 summarizes the distribution of ages, with apparent recruitment clusters appearing at $4-6,8-9,11-13$, and $17-20$ years.
The 10 trees that were intermediate to $T$. aphylla or T. ramosissima at Site 1 formed flower buds, but only 1 flowered and none set seed. These intermediates resembled T. ramosissima with their shrub-like growth habit, yellow green foliage, and floral arrangement on the inflorescences, but they resembled $T$. aphylla in their height and nondeciduous foliage (only T. ramosissima is deciduous). They were intermediate in the degree of clasping of leaves (tighter than T. ramosissima, looser than T. aphylla) and in the yellow color of the autumn leaves. Gaskin and Shafroth (2005) confirmed that these morphological intermediates were genetically distinct hybrids.

\section{Discussion}

Tamarix aphylla at Lake Mead National Recreation Area in southern Nevada produces germinable seeds, just as it does in Australia (Griffin et al. 1989) and Israel (Waisel 1960a). This discovery provides the first evidence of 


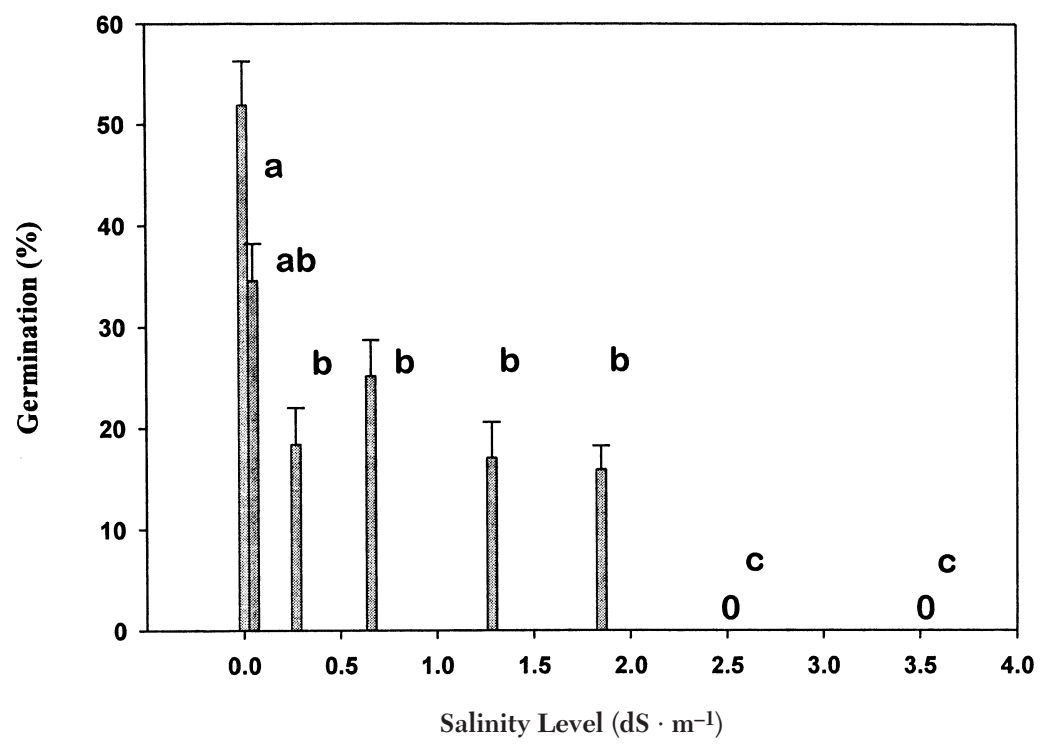

Fig. 3. Mean germination percentages $\left( \pm 1 s_{\bar{x}} ; n=3\right.$ petri dishes per treatment) for Tamarix aphylla seeds treated with $\mathrm{NaCl}: \mathrm{CaCl}_{2}$ solutions of varying concentrations. Germination values with the same lowercase letters are not significantly different $(P>0.05)$.

sexual reproduction in the USA and contradicts suggestions that T. aphylla is sterile in the southwestern USA (Hoddenbach 1989, Neill 1989). Potentially high seed production, combined with average germination rates of $21 \%$ under lab conditions, a seeding season of up to 3 months, some evidence of seedling establishment, and a history of aridland invasion elsewhere, make T. aphylla a potential invader of southwestern riparian communities. The production of germinable seeds in $T$. aphylla populations at LMNRA was highly variable among sites $(8 \%-32 \%)$ and individual trees $(0 \%-66 \%)$, suggesting that potential fecundity is influenced both by environmental factors among sites and more localized microsite differences. We did not examine intrinsic (i.e., genetic) factors that might also influence fecundity. We further note that potentially substantial genetic mixing since its introduction may have altered the reproductive capacity of $T$. aphylla.

Environmental signals such as photoperiod, irradiance, temperature, and water availability often control phenological events, either promoting or delaying flowering (Lyndon 1992), seed production, or growth (Bazzaz et al. 2000). During our study, a severe drought began, with a concomitant drop in the water level of Lake Mead from $368.0 \mathrm{~m}$ above sea level (ASL) in June 2000 to $351.4 \mathrm{~m}$ ASL in December 2002. We found a parallel decline in both the duration of seeding (from 84 to 13 days) and the proportion of $T$. aphylla trees producing seeds (from 62\% to 25\%), suggesting that groundwater availability is a critical environmental control (Lyndon 1992) at LMNRA for a facultative phreatophyte such as T. aphylla.

Low water availability limits germination of T. aphylla in its native Israel where seeds are produced in September, long before the seasonal rains in mid-November (Waisel 1960a). Short-term seed viability compounds the issue. Our study showed that T. aphylla seeds survived for 4 weeks in dry storage, but $<1 \%$ germinated after 1 week under (dry) field conditions. Even under ideally moist laboratory conditions, half the seed germination occurred within 3.4 days. We were not able to obtain germination of seeds watered in the field, perhaps due to high soil salinity (see below). Therefore, if adequate soil moisture is not available within a few days of seed release, seeds may not germinate.

The failure of $T$. aphylla seeds to germinate within stands of adult T. aphylla at LMNRA (even when we experimentally removed litter and added water) was probably due to inhibition by salty soils. Competition with existing trees for light, water, or nutrients might be an 
additional restraint, but seedlings of both $T$. aphylla and T. ramosissima establish at high densities at LMNRA, so competition among juvenile congeners does not seem limiting. Salty soils, perhaps in combination with seed age (Waisel 1960a), prevented T. aphylla germination within the adult stand, yet viable seeds produced by those adults are now germinating on the receding shoreline along with the more numerous $T$. ramosissima. TallentHalsell (1998) found that the shoreline of Lake Mohave (immediately downstream from Lake Mead) was less salty than soils in near-shore $T$. ramosissima stands. Native Populus and Salix species also germinate under conditions of receding water, but limited local seed sources reduce their success (Stromberg 1993, TallentHalsell and Walker 2002). Inundation from rising water levels is not conducive to germination of T. aphylla, T. ramosissima, or native Populus or Salix trees.

A clearly defined band of T. aphylla was found between $67.5 \mathrm{~m}$ and $82.5 \mathrm{~m}$ (shoreward edge) and $172.5 \mathrm{~m}$ and $187.5 \mathrm{~m}$ (inland edge) from the baseline (370.0-375.5 m ASL; distances tightly correlated with elevation). Tamarix ramosissima was found closer to the baseline than T. aphylla and closer to desert vegetation dominated by Larrea tridentata and Ambrosia dumosa (A. Gray). W.W. Payne delineated the upper elevational boundary of the T. aphylla zone. Tamarix leaf litter tended to be deepest and soil salinity tended to be highest in the $T$. aphylla zone. Tamarix aphylla litter is resistant to decomposition and increased soil salinity in Israel (Litwak 1957). What was unusual at LMNRA, however, was the co-occurrence of T. aphylla and T. ramosissima.

In Australia, T. aphylla, but not T. ramosissima, is considered a serious weed (Thorp and Lynch 2000), and we know of no reports of ecological interactions between the 2 species of Tamarix. The 2 species appear to partition the drawdown zone at LMNRA because $T$. ramosissima cover declined with increasing distance from the baseline (increased elevation). The taller T. aphylla may successfully outcompete the shorter T. ramosissima as water table depths increase. Alternatively, because the 2 species lack a complete overlap in their seed dispersal phenology, the zonation may be due to chance coincidences between seed availability and receding shorelines. 

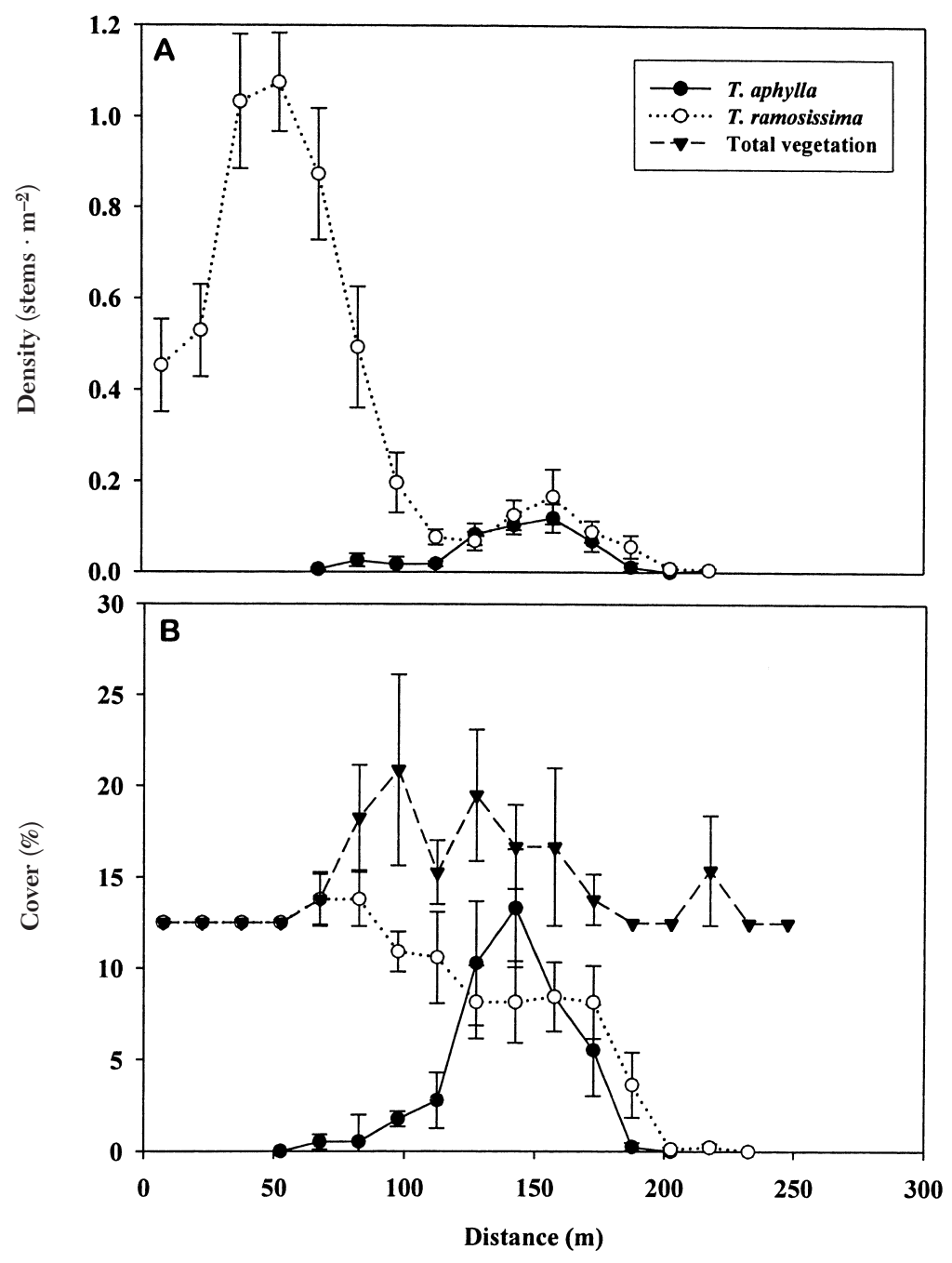

Fig. 4. (A) Mean stem density and (B) cover $\left( \pm 1 s_{\bar{x}} ; n=214\right.$ plots) of Tamarix ramosissima and T. aphylla. Distance is from the baseline close to the lakeshore. All sites are combined.

Hybrids among species of Tamarix are common (Gaskin and Schaal 2002), but this is the first finding of hybrids between T. aphylla and T. ramosissima. Samples of the 3 phenotypes found at LMNRA represented 3 genotypes $(T$. aphylla, T. ramosissima, and a hybrid; Gaskin and Shafroth 2005). We do not know what reproductive or invasive characteristics this hybrid will exhibit, because, to date, no seed production has been observed at Lake Mead. However, Gaskin and Shafroth (2005) report viable seeds from 1 individual of a similar hybrid found along the Colorado River near Blythe, California.

Tamarix aphylla trees are clearly capable of invading riparian areas such as LMNRA. The high water level of $373.4 \mathrm{~m}$ ASL in 1983 roughly corresponds with the elevations of the upper edges of the T. aphylla stand at our 3 study sites (370.0-375.5 m ASL) and likely provided a receding shoreline for germination, similar to what is now occurring. The oldest trees at our sites were estimated to be 20 years old, corresponding with the 1983 high water levels. Clusters of younger trees coincide approximately with subsequent fluctuations of Lake Mead levels (due to variable human use and snow pack in the Rocky Mountains upstream). While vegetative reproduction of T. aphylla was not examined in this study, we observed a number of stem sprouts from fallen, detached 
TABLE 3. Number of T. aphylla trees in each age group compared to annual high lake level and precipitation during presumed year of establishment. Ring counts have an assumed accuracy of \pm 1 year $(n=23$ usable tree rings).

\begin{tabular}{|c|c|c|c|c|}
\hline $\begin{array}{c}\text { Age } \\
\text { (annual rings) }\end{array}$ & $\begin{array}{c}\text { Number of } \\
\text { trees }\end{array}$ & $\begin{array}{c}\text { Year of } \\
\text { establishment }\end{array}$ & $\begin{array}{c}\text { Annual high lake } \\
\text { level elevation } \\
(\mathrm{ft}, \mathrm{m})\end{array}$ & $\begin{array}{c}\text { Average } \\
\text { precipitation } \\
(\mathrm{cm})\end{array}$ \\
\hline 4 & 3 & 1999 & $1213.96,370.01$ & 4.01 \\
\hline 5 & 1 & 1998 & $1215.95,370.62$ & 7.47 \\
\hline 6 & 1 & 1997 & $1214.65,370.22$ & 9.06 \\
\hline 7 & 0 & 1996 & $1195.04,364.25$ & 2.41 \\
\hline 8 & 1 & 1995 & $1190.92,362.99$ & 5.76 \\
\hline 9 & 1 & 1994 & $1190.98,363.01$ & 3.94 \\
\hline 10 & 0 & 1993 & $1193.75,363.86$ & 8.52 \\
\hline 11 & 2 & 1992 & $1180.55,359.83$ & 11.18 \\
\hline 12 & 4 & 1991 & $1180.19,359.72$ & 7.87 \\
\hline 13 & 1 & 1990 & $1191.88,363.29$ & 5.34 \\
\hline 14 & 0 & 1989 & $1202.57,366.54$ & 3.03 \\
\hline 15 & 0 & 1988 & $1211.82,369.36$ & 3.01 \\
\hline 16 & 0 & 1987 & $1210.83,369.06$ & 7.43 \\
\hline 17 & 2 & 1986 & $1213.20,369.78$ & 5.09 \\
\hline 18 & 2 & 1985 & $1214.36,369.53$ & 4.13 \\
\hline 19 & 1 & 1984 & $1213.73,369.94$ & 13.36 \\
\hline 20 & 4 & 1983 & $1225.85,373.64$ & 7.35 \\
\hline
\end{tabular}

stems, and we suspect that T. aphylla initially spread vegetatively into LMNRA from upstream populations, much as it did in Australia (Griffin et al. 1989).

We expect that, without aggressive control efforts, T. aphylla will continue to invade the shorelines of Lake Mead. The production of many seeds, potentially high germination rates, and frequent vegetative reproduction suggest potential for rapid spread (Kolar and Lodge 2001). Once established, T. aphylla litter salinizes soils and alters hydrologic regimes in its native habitat (Waisel 1960b, 1961). If such effects are also occurring at LMNRA, there could be a potential altering of ecosystem functions and resulting loss of native riparian species. Further, the impact of T. aphylla may compound the well-documented and similar problems stemming from $T$. ramosissima invasions (Brock 1994, Walker and Smith 1997, Everitt 1998) because T. aphylla is larger, taller, and produces more salinizing litter than its congener. Further examination of the impacts of T. aphylla are clearly important, now that its potential for spread has been suggested. The possibility of hybrids with unknown invasive abilities further suggests that T. aphylla should be removed from LMNRA and other riparian corridors throughout the desert Southwest.

\section{ACKNOWLEDGMENTS}

We thank Josh Hoines, Jeff Holland, Vincent Ossana, and Nicole Sikula for field and laboratory assistance; Dale Devitt for help with soil salinity measurements; Daniel Thompson for statistical advice; and Paula JacobyGarrett for providing Fig. 1. John Gaskin, Pat Shafroth, and 1 anonymous reviewer provided helpful comments on the manuscript. The National Park Service funded this work through a grant to the University of Nevada, Las Vegas.

\section{Literature Cited}

AbD El-Ghani, M.M. 2000. Vegetation composition of Egyptian inland salt marshes. Botanical Bulletin of Academia Sinica 41:305-314.

ALPKEM. 1991. Total Kjeldahl nitrogen. The flow solution methodology. Wilsonville, OR.

BAUM, B. 1967. Introduced and naturalized tamarisks in the United States and Canada. Baileya 15:19-25.

1978. The genus Tamarix. The Israel Academy of Sciences and Humanities, Jerusalem, Israel.

BARNES, P. 2003. Reproductive and population characteristics of Tamarix aphylla at Lake Mead National Recreation Area, Nevada. Master's thesis, University of Nevada, Las Vegas.

BazZaz, F., D. Ackerly, and E. Reekie. 2000. Reproductive allocation in plants. Pages 1-23 in M. Fenner, editor, Seeds: the ecology of regeneration in plant communities. CAB International, New York.

BRock, J.H. 1994. Tamarix spp. (salt cedar), an invasive exotic woody plant in arid and semi-arid riparian habitats of western USA. Pages 27-44 in L.C. de Waal, L.E. Child, P.M. Wade, and J.H. Brock, editors, Ecology and management of invasive riverside plants. John Wiley \& Sons, Chichester, U.K.

BrokaW, N.V.L. 1998. Fragments, past, present and future. Trends in Ecology and Evolution 13:382-383.

Brotherson, J., S. Rushforth, W. Evenson, J. Johanson, And C. Morden. 1983. Population dynamics and age 
relationships of eight tree species in Navajo National Monument, Arizona. Journal of Range Management 36:250-256.

Brotherson, J., J. Carman, and L. Szyska. 1984. Stemdiameter age relationships of T. ramosissima in central Utah. Journal of Range Management 37:362-364.

Busch, D.E., AND S.D. SMITH. 1995. Mechanisms associated with decline of woody species in riparian ecosystems of the southwestern U.S. Ecological Monographs 65:347-370.

Cleverly, J.R., S.D. Smith, A. SAla, and D.A. DevitT. 1997. Invasive capacity of Tamarix ramosissima in a Mojave Desert floodplain: the role of drought. Oecologia 111:12-18.

Cronk, C., AND J. Fuller. 1995. Plant Invaders. Chapman and Hall, London.

Danin, A. 1981. Ecological factors affecting the distribution of Tamarix aphylla in Israel and Sinai. La-Yaaren 31:46-48.

1999. Desert rocks as plant refugia. Botanical Review 65:93-170.

Di Tomaso, J. 1998. Impact, biology and ecology of saltcedar in the southwestern United States. Weed Technology 12:326-336.

Dynesius, M., AND C. Nilsson. 1994. Fragmentation and flow regulation of river systems in the northern third of the world. Science 266:753-762.

EveritT, B.L. 1998. Chronology of the spread of tamarisk in the central Rio Grande. Wetlands 18:658-668.

Fuller, M. 1998. Athel pine. Agnote 539, No. F61. Northern Territory Government, Department of Business, Industry and Resource Development, Alice Springs, Australia. Available from: http://www.ipe.nt.gov.au/ whatwedo/weeds/pdf/tamarixaphylla.pdf

Gaskin, J.F., and P.B. Shafroth. 2005. Hybridization of Tamarix ramosissima and T. chinensis (saltcedars) with T. aphylla (athel) (Tamaricaceae) in the southwestern USA determined from DNA sequence data. Madroño 52:1-10.

Gaskin, J.F., and B.A. SchaAl. 2002. Hybrid Tamarix widespread in U.S. invasion and undetected in native Asian range. Proceedings of the National Academy of Science USA 99:11256-11259.

Goldsmith, F.B., and N. SMart. 1982. Age, spacing and growth rate of Tamarix as an indication of lake boundary fluctuations at Sebkhet Kelbia, Tunisia. Journal of Arid Environments 5:43-51.

Griffin, G., D. Smith, S. Morton, G. Allan, and K. MASTERS. 1989. Status and implications of the invasion of tamarisk ( $T$. aphylla) on the Finke River, Northern Territory, Australia. Journal of Environmental Management 29:297-315.

Haigh, S.L. 1998. Stem diameter-age relationships of Tamarix ramosissima on lake shore and stream sites in southern Nevada. Southwestern Naturalist 43: $425-429$.

Hoddenbach, G. 1989. Tamarix control. Pages 116-125 in M.R. Kunzmann, R.R. Johnson, and P. Bennett, technical coordinators, Tamarisk control in southwestern United States. Special Report No. 9, National Park Service, Tucson, AZ.

Kolar, C.S., AND D.M. Lodge. 2001. Progress in invasion biology: predicting invaders. Trends in Ecology and Evolution 16:199-204.

LiTWaK, M. 1957. The influence of T. aphylla on soil composition in the northern Negev of Israel. Bulletin of Resources Council of Israel 6D:38-45.
Lyndon, R. 1992. The environmental control of reproductive development. Pages 9-32 in C. Marshall and J. Grace, editors, Fruit and seed production: aspects of development, environmental physiology and ecology. Cambridge University Press, Cambridge, U.K.

Lyon, H. 1924. The athel in Hawaii. Hawaiian Planter's Record 28:508-510.

MCLEAN, E.O. 1982. Soil pH and lime requirement. Pages 199-209 in C.A. Black, editor, Methods of soil analysis. American Society of Agronomy, Madison, WI.

Meyers-Rice, B. 1997. Weed notes: Tamarix aphylla. The Nature Conservancy. Available from: http://ncweeds. ucdavis.edu/esadocs/tamaaphy.html

NEILL, W.M. 1989. Volunteers play role in tamarisk control in desert riparian communities (California). Restoration Management and Notes 7:48.

RhodDEs, J.D. 1982. Soluble salts. Pages 167-173 in C.A. Black, editor, Methods of soil analysis. American Society of Agronomy, Madison, WI.

Sala, A., S. Smith, and D. DevitT. 1996. Water use by $T$. ramosissima and associated phreatophytes in a Mojave Desert floodplain. Ecological Applications 6:888-898.

Sher, A.A., And D.L. Marshall. 2003. Seedling competition between native Populus deltoides (Salicaceae) and exotic Tamarix ramosissima (Tamaricaceae) across water regimes and substrate types. American Journal of Botany 90:413-422.

Sher, A.A., D.L. Marshall, AND J.P. TaYlor. 2002. Establishment patterns of native Populus and Salix in the presence of invasive nonnative Tamarix. Ecological Applications 12:760-772.

STATISTIX. 2002. Statistix 7 user's manual. Analytical Software, Tallahassee, FL.

StromberG, J.C. 1993. Fremont cottonwood-Goodding willow riparian forests: a review of their ecology, threats and recovery potential. Journal of the Nevada Academy of Science 26:98-110.

Tallent-Halsell, N.G. 1998. Lake Mohave riparian ecology and restoration. Master's thesis, University of Nevada, Las Vegas.

Tallent-Halsell, N.G., and L.R. Walker. 2002. Responses of Salix gooddingii and Tamarix ramosissima to flooding. Wetlands 22:776-785.

ThorP, J., AND R. LyNCH. 2000. The determination of weeds of national significance. National Weeds Strategy Executive Committee, Australia. Available from: http:// www.weeds.org.au/docs/wons/.

WAISEL, Y. 1960a. Ecological studies on T. aphylla: distribution and reproduction. Phyton 15:7-17.

. 1960b. Ecological studies on T. aphylla: the water economy. Phyton 15:19-29.

1961. Ecological studies on T. aphylla: the salt economy. Plant and Soil 13:356-364.

WALKER, L.R., AND S. SMITH. 1997. Impacts of invasive plants on community and ecosystem properties. Pages 69-86 in J.O. Luken and J.W. Thieret, editors, Assessment and management of plant invasions. Springer-Verlag, New York.

Williams, P.A., AND S. Wiser. 2004. Determinants of regional and local patterns in the floras of braided riverbeds in New Zealand. Journal of Biogeography 31:1355-1372.

Received 20 December 2004 Accepted 26 August 2005 